\title{
Perceptions of Age Generations Regarding Employee Satisfaction in a South African Organisation
}

\author{
Nico Martins \\ Department of Industrial and Organisational Psychology Unisa \\ Martin@unisa.ac.za
}

\section{Ellen Caroline Martins}

Organisational Diagnostics

Doi:10.5901/mjss.2014.v5n21p129

\begin{abstract}
The aim of the paper is to determine empirically through quantitative research the satisfaction levels of employees from the different age generation groups. This focus is on the perceptions of Millennials, Generation Xers and Baby-Boomers in an organisation with a population of 27611 employees. Structural equation modelling was used to confirm the reliability and validity of the questionnaire and the data was analysed by means of the Kuskall-Wallis test. The results indicate similarities between the three generations, but also significant differences. It appears from the results that management needs to focus on the needs and expectations of the various generations to improve overall employee satisfaction. They should especially note the different expectations and needs of the younger generations.
\end{abstract}

Keywords: Baby-Boomers, Generation Xers, Millennials, employee satisfaction, managerial practices, age generations

\section{Introduction}

Interest in the concept of generations appears to be on the increase. According to Robbins and Judge (2010:49), an understanding that individuals' values differ but reflect the societal values of the period in which they grew up can be a valuable aid in explaining and predicting behaviour. While organisations have developed policies and programmes to promote diversity in race, culture and gender, generational diversity has yet to be addressed (Rich, 2012). At the annual conference of the Society for Industrial and Organizational Psychology (SIOP) which was held in San Diego, USA in April 2012 a number of presentations focusing on generations were included. Keynote speakers provided the audience with ideas for research directions to increase understanding of the aging workforce around the world (Finkelstein, 2012). Typical presentations focusing on different generation groups were about millennials and leadership, their competency based job performance and developing millennials to lead for innovation.

Worldwide problems in understanding the different generation groups relate to a notable lack of information, and many anecdotes and stereotypes. The popular press continues to bemoan the great generational divide at work, especially concerning Millennials. Often such reports seem overly generalised, however, and based either on anecdotal evidence or data not open to critical peer review (Macky, Gardner \& Forsyth, 2008). They furthermore argue that more empirical research on generational differences at work, especially controlling for age and time period, is needed. Research done in a South African context is fairly limited in comparison to the vast body of research conducted internationally. A challenge in the South African context that might have a major impact on organisations in the talent retention sphere, was exposed by research conducted in partnership with the University of Pretoria and commissioned by Johnson Controls International (Oxygen Country Report, 2010). The challenge relates to the large generational gap that is looming due to the high HIV prevalence in South Africa resulting in low life expectancy. In South Africa, as in many other developing countries, it appears that youth available for employment (15-34 years of age) have a low marginal utility in the labour market compared with older, and often more educated and experienced, workers/job seekers (Van Aardt, 2012). These situations could cause a skills shortage in the workplace.

Masibigri and Nienaber (2011) express the talent retention challenge as follows: "Retaining the right talent in South African organisations, as is the case internationally, is challenging because of recent phenomena like the struggle for talent, skills shortages, employee mobility and the imminent retirement of Baby-Boomers. This situation will become worse if organisations do not handle recessionary lay-offs properly. These phenomena adversely affect the ability of 
organisations to create and maintain their competitive advantage and their consequent performance" (Masibigiri \& Nienaber, 2011, p 319). Dressler (2009) calls the "ageing workforce" the biggest demographic trend impacting employers.

Employee satisfaction seems to play a major role in the retention of employees. When employees are not engaged in their work and are unsatisfied with their working conditions and the organisational practices, they will leave (Masibigiri \& Nienaber, 2011).

The different age generations have different characteristics, needs and a different set of values that impact on the workplace. Lancaster and Stillman (2002) state that different generations shaped by different values, standards and policies are not necessarily compatible with the next generation. They believe that "organisations that can understand and bridge generation gaps have a real competitive edge in the retention game." A better understanding of what drives the different generations and keeps them satisfied might assist managers to retain the best talent.

The main aim of the paper is to determine empirically through quantitative research the satisfaction with organisational practices of employees from the different age generation groups in a South African organisation. Understanding the satisfaction levels of the different age generation groups might indicate focus areas in addressing the challenge of retaining skilled talent, specifically Millennials.

The aims of this paper are structured as follows: The concepts of age generations and employee satisfaction are conceptualised. Employee satisfaction of the different generation groups is discussed. The value of an employee satisfaction audit is discussed, followed by the description of the research methodology to analyse the perceptions of the different age generations regarding employee satisfaction. The research results are described followed by a discussion and conclusions.

\section{Conceptualising Age Generations}

A generation is defined by common attitudes, experiences and preferences that develop as a result of certain events which had a major impact on their lives (Moore \& Bussin, 2012; Rich, 2010). Lancaster and Stillman (2002) believe that age ranges to classify generations are merely guidelines and that it is the common history of events and conditions that each individual experiences during the formative years that determine who they are as a group and how they see the world. The researchers believe that age classification is useful to classify and compare the different generations in the workplace.

Different authors classify and date the different workforce generation groups differently. Lancaster and Stillman (2002) classify Millennials as born between 1981 and 1999; Generation Xers born between 1965 and 1980 and BabyBoomers between 1946 and 1964. The following classification of Garlick and Langley (2007) and DeLong (2004), which was used in this research, is very similar, except for Generation Xers going up to 1977, making Millennials three years older.:

- Millennials (or Generation-Y) born between \pm 1978 and 2000

- Generation Xers born between 1965 and 1977

- Baby-Boomers born between 1946 and 1964

Conditions such as major world events like World War II, the 9/11 attacks on New York and the first democratic elections in South Africa in 1994 (Moore \& Bussin, 2012; Rich, 2010); and economic upheavals that affect the wealth and health of each person permanently shape the way they look at the world (Lancaster \& Stillman, 2002). Changing world events since 1989 such as the fall of the Berlin Wall, symbolising the end of a decades-long struggle between communism and capitalism, and the creation of the World Wide Web in 1990 that ended up by opening up the Internet to the general public and the scientific community, have shaped the lives of especially the Millennials. Other examples relating to technological changes, the collapse of the Soviet Union in 1991 (The List Blog, 2011), and in South Africa the release of Nelson Mandela from prison on 11 February 1990 (Codrington \& Grant-Marshall, 2006), have contributed to the radically changed landscape.

Characterising the different age generations in the current world might provide a better understanding of how they differ in a social context and in the workplace. Characteristic of Millennials in general is that they tend to move around in their jobs more often than other generation groups and are less likely to remain at a single company throughout their career (Hamilton, 2011). Workforce.com states that large companies do not move fast enough for Millennials. Thus they switch employers with a view to exposing themselves to new and different things. Millennials have a need for immediate gratification; many have high expectations, but are willing to put in the effort it takes to achieve their goals. Hamilton (2011) cites HBR.org as having reported that Millennials set high standards for themselves, are used to overachieving academically and to making a strong personal commitment to community service. HBR.org (cited in Hamilton, 2011) quotes: "Keep them engaged, and they will be happy to overachieve for you." 
Millennials in South Africa consist of a group of South Africans who are old enough to be part of the old regime, but not old enough to have participated in it, and a new generation of South Africans born into a new world order, including a new South Africa. This group, referred to as the "born free" generation, is largely black and has grown up in a world different to that which their parents knew. With increased racial integration and access to global media "a melting pot of culturally integrated values and viewpoints is emerging amongst South African youth" (Smith, 2011). The younger group thus does not perceive apartheid the same way as their parents did. Both white and black South African Millennials have more in common with one another because of global influences and less and less in common with their parents and grandparents. There is an increasing trend toward a global "one world culture" (Smith, 2011).

South African Millennials are a more diverse group than their global counterparts. According to Chang (2011), South African Millennials are affected by a job market that is difficult to enter and by soaring unemployment, among other social ills, which generate a disaffected and angry generation of Millennials. They have started to enter the workforce, are highly educated and therefore more opinionated, sophisticated and technologically savvy (being connected 24/7), highly achievement-oriented, highly energised within a team structure and having business sustainability at the top of their minds (Chang, 2011; Systemic Logic.com 2011). Being well-educated and technologically savvy, Millennials are able to bring valuable knowledge to the table that can be crucial for a company's success. However, they lack experience, soft skills such as relationship building, communication, meeting deadlines and organisation (Chang, 2011). Their managers and parents, mostly Baby-Boomers, generally have more experience and value the soft skills that they lack, which not surprisingly leads to rising conflict in the workplace. This is no ordinary generational clash bearing in mind the phenomenal technological changes and global influences that moulded the South African Millennial mindset (Chang, 2011).

Other characteristics that can be associated with South African Millennials are that they are very family-centric and attention-seeking, which means that if these needs are not met, frustration may arise and many talent attraction and retention strategies aimed at this segment of the workforce will fail (Alexander, 2011). Having been impacted by globalisation and international influences, South African Millennials are self-confident, optimistic, hopeful, independent, determined, goal driven, success driven, lifestyle centred, diverse but inclusive, global, civic, community minded and entrepreneurial. The word "entitled" is often used to describe this group in South Africa (Smith, 2011).

Generation X employees born between 1965 and 1977 were, similar to the Baby-Boomers, greatly affected by apartheid in South Africa. They were typically the young people who attended military training. Furthermore, they tend to be sceptical and pragmatic and value leadership by competence (Cordeniz, 2002). They have little respect for service, title or rank because their parents had it all but lost their jobs anyway (DeMarco, n.d.; Lancaster and Stillman, 2002). "Generation Xers tend to put more faith in themselves as individuals and less faith in the institutions that seem to have failed them time and again." They are an extremely resourceful and independent generation who learned at an early age to rely on themselves and who count on their peers to get things done. They experience "freedom" and flexibility as the ultimate reward, (Lancaster \& Stillman, 2002), need to belong and want meaningful work (Perrine, 2009; Vaughn, 2008). According to Masibigiri and Nienaber (2011), Generation X employees are losing their trust in, and loyalty to their organisations and fear boredom. Organisations must retain them if they are to create and sustain their competitive advantage because Generation X employees are human capital repositories of knowledge, skills and expertise, and ensure good performance. According to the two authors the retention of Generation X employees is important because they are the knowledge repositories of organisations. They help to create and sustain competitive advantage and to achieve organisational goals and good performance. However, Generation X employees are nomadic and they are more likely than any other generation to leave their organisation when dissatisfied.

Baby-Boomers were shaped by the Cold War, Civil Rights Movements, Women's Liberation Movement, television and rock and roll (Lancaster \& Stillman, 2002; Espinoza, Ukleja \& Rusch, 2010). The key words to describe BabyBoomers are "optimistic" and "competitive". The post-war economy of job availability and promise of good education for all allowed Boomers to grow up in a world rich with opportunity, which gave them a sense that anything was possible. They are labelled the "me generation" partly because they were privileged to focus on themselves with a deep identification of who they are and where they are going and what they can achieve at work. Money, title and recognition are important to them. They are motivated by what they accomplish at work. Interpersonal communication (on a face to face level) is important to them. The majority plan to never retire, but intend to keep working in some form as long as they can be productive (Lancaster \& Stillman, 2002).

The transfer of knowledge by the Baby-Boomers to Generation Xers and Millennials is one of the issues organisations struggle with. Dressler (2009) reports findings in which it was observed that $41 \%$ of surveyed employees are bringing retirees (Baby-Boomers) back into the workforce, and 31\% are offering employment options designated to attract and retain senior retired workers. The competitive Baby-Boomers have always felt that knowledge is power and in 
tough economic times are hanging onto what they know as it may provide job security (http://tcbmag.blogs.com Igenerations/knowledge-transfer, 15 October 2011). Understanding the different generations and in particular Millennials in South Africa, on whom the future of business is largely dependent, would mean older generations and particularly managers (who are mostly Baby-Boomers and Generation X employees) would be better able to connect with them, as Millennials are already forming part of the workplace.

\section{Conceptualising Employee Satisfaction and the Different Age Generations}

The concepts of job satisfaction and employee satisfaction are defined to clearly understand the focus of this research study. According to Kreitner and Kinicki (2008), job satisfaction can be defined as an affective or emotional response towards various aspects of one's job. Job satisfaction has also been defined in terms of attitudes that individuals have towards their jobs (Weiss 2002). Schneider and Snyder (1975) define job satisfaction as a personal evaluation of the current conditions of the job or the outcomes that arise as a result of having a job. Lancaster and Stillman (2002) reiterate as follows: "Organisations that understand generational differences and adjust their recruitment and retention strategies are reaping bottom-line rewards in terms of an increased success rate with job candidates and higher overall job satisfaction."

Employee satisfaction has been described as a pleasurable or positive emotional state resulting from an employee's appraisal of his or her company environment or company experience (Rollinson, 2005). According to researchers employee satisfaction is closely related to job satisfaction and the intention to leave or stay with the organisation (Westover, 2011; Robinson, 2006). There is convincing evidence that where job satisfaction is high, labour turnover is reduced (Aamodt, 2007). Job satisfaction is therefore probably one of those experiences of work that makes it less likely that an employee will think about leaving even if there are available opportunities. However, if job satisfaction is absent and there are other opportunities, turnover could well increase. Employee satisfaction is also closely related to employees' needs and work expectations. Individual motivation, levels of satisfaction and work performance are determined by the comparative strength of the needs and expectations of various biographical or demographical groups, and the extent to which they are met or not met (Aamodt, 2007; Robinson, 2006). According to Espinoza, Ukleja and Rusch (2010), Millennials "do not have the same need or know-how to build relationships with their managers or authority figures". Previous generations had to take the initiative in building relationships to obtain information. Millennials who have wireless laptops/smartphones at their fingertips don't ask questions (and believe they have access to any information they need). On the other hand they desperately want mentors and career advocates. Baby-Boomers know how to reach upward and do not feel the need to reach downward

Research by Döckel, Basson and Coetzee (2006) indicates that extrinsic and intrinsic factors such as compensation, supervisor support and work/life balance policies are significant factors in retaining high technology employees. Training and development and career opportunities were also found to be significant retention factors (Kochanski \& Ledford, 2001; McElroy, 2001). Bjornebekk (2008) postulated that employees who are satisfied with rewards would feel obliged to invest their efforts in the organisation. Therefore, employee satisfaction has activating and motivational potential. According to research done by PricewaterhouseCoopers (PWC), training and development is the most highly valued benefit for Millennials in the first five years of their career, with one third of respondents electing this as their first choice benefit (aside from salary). In South Africa, the respondents' first choice was flexible working hours with training and development as their second choice and financial assistance with housing as their third choice (www.pwc.com/za/en/pres-room/managing-tomorrows-people.jhtml). Employee satisfaction thus reflects the degree to which the individual's needs and desires are met as well as the extent to which these are perceived by other employees (Küskü, 2003). Comm \& Mathaisel (2000) describe employee satisfaction as the gap between the work-related perceptions and expectations of employees in an organisation. This implies that those employees' needs, wants and expectations need to be satisfied across a range of related organisational variables (O'Neil, 2005).

Employee satisfaction influences organisational performance as much as customer satisfaction (Burke, Graham \& Smith, 2005). According to O'Neil (2005:133), "the key to satisfied customers and increased profits is the satisfied employee in the customer service or boundary role".

It is crucial for organisations to improve and sustain employee satisfaction because of the visible signs of employee dissatisfaction, which include employee turnover, deviant behaviour and property and production deviance (O'Neil, 2005; Kulas, Mclnnerney, DeMuth \& Jadwinski, 2007). According to Kulas et al (2007:390), "it is clear that employee deviance is a costly burden on organisations, but the antecedents and processes through which such deviant behaviour is manifest are not apparent". The above discussion indicates that a number of behavioural aspects influence employee satisfaction. According to Ledimo (2012) research indicates that employee satisfaction benefits include employee retention, customer 
satisfaction, improved quality, improved performance, life satisfaction, employee health and well-being.

The literature indicates that numerous studies were conducted on the construct of employee satisfaction in the organisational sciences, with over 5000 articles and dissertations published on the topic (Locke, 1976; Küskü, 2003; O'Neil, 2005). Studies conducted on employee satisfaction both internationally and nationally focused on the actual antecedent factors of employee satisfaction and other factors that enable organisations to attract, motivate and retain employees. These factors include productivity, customer satisfaction, employee loyalty and performance (Abott, 2003; Burke et al, 2005; O'Neil, 2005). However, there is a need to conduct a study which focuses more specifically on the relationship between the different generations and job satisfaction.

A number of studies (Crites, 1969; Arvey, Carter \& Buerkley,1991; Van Rooyen \& Keyse, 2011; Martins \& Coetzee, 2007) have explored the relationship between age and job satisfaction but did not specifically focus on the generational groups as defined in this study.

The focus of this research is to specifically investigate the perceptions of three age generation groups (Millennials, Generation Xers and Baby-Boomers) in relation to their employee satisfaction with organisational practices.

\section{Importance of Employee Satisfaction in Retaining the Various Age Generations}

In an increasingly competitive, turbulent business environment and the continuously changing world of work, the subsequent dramatic change in the role of supervisors, and the effective resourcing, management and retention of human capital remain crucial factors of organisational survival, adaptation and competitive advantage (Michaels, Hardfield-Jones \& Axelrod, 2001; Ndlangamandla, 2011; Robinson, 2006). Managing retention and keeping labour turnover to target (particularly with regard to core employees or knowledge workers) has become a key strategic issue for organisations (Döckel, Basson \& Coetzee, 2006).

According to Ndlangamandla (2011) employees' satisfaction and retention have always been important issues for industrial psychologists. In a global survey in 2009 by PWC which focused on Millennials at work, one of the interesting findings was that CEOs are struggling with Millennials because they need more information about what drives them (www.pwc.com/za/en/pres-room/managing-tomorrows-people.jhtml). In this regard it is widely recognised that the satisfaction level of employees is a critical part of attracting and retaining them (Lawler \& Finegold, 2000; Pollitt, 2005; Robinson, 2006).

Research in South Africa indicates that retaining Generation X employees, in particular, is important for both the private and public sectors. The retention problem may be even worse for the public sector as there are fewer financial rewards in the public service than in the private sector (Masibigiri \& Nienaber, 2011). These demands on organisations have led to a renewed interest in employee attitude surveys in an attempt to establish why people leave and what may be done to retain them (Pollitt, 2005; Robinson, 2006). In agreement with this, Rollinson (2005) states that the attention given to organisational culture and employee satisfaction surveys as a means of predicting employees' commitment to and satisfaction with the company is one of the most prominent trends in organisations today. Employee surveys typically focus on reporting demographics (such as generation groups) of the persons who participated in the survey. These subanalyses can assist managers in deciding whether there are any needs, issues or problems relevant to a specific group for example, whether junior staff members have different concerns to senior staff members or if a specific generation group has specific expectations of the organisation. Organisations can then target interventions and decision-making accordingly (Borg \& Mastrangelo, 2008). Researchers such as Margaret Mead, Morris Massey, William Strauss and Neil Howe with their book Generations: The history of America's future, explained and interpreted generations' different perceptions, values and attitudes (Codrington \& Grant-Marshall, 2006). In contrast in the South African context very few studies have been conducted to investigate the impact of the various generation groups on organisational variables such as employee satisfaction.

Employee satisfaction surveys might just provide the information to manage different generation groups more effectively and strategically.

\section{Value of Employee Satisfaction Audit}

The process of conducting an employee satisfaction survey or audit is diagnostic in nature. According to French and Bell (1999:105), a diagnostic process "identifies strengths, opportunities and problem areas". An employee satisfaction survey is used as a diagnostic method to collect data that will enable an organisation to develop a picture of its strengths, opportunities, threats and developmental areas in relation to its employees' satisfaction. It also indicates which factors are most important or critical in understanding, predicting and controlling organisational behaviour (Nadler \& Tushman, 1980). 
An employee satisfaction audit is critical to guide organisational psychologists in the analysis of and possible action to enhance employee satisfaction. According to Chen et al (2006:486), "the purposes of employee satisfaction surveys are not only to discover employee satisfaction levels, but also to determine necessary improvements via the results of employee satisfaction surveys". Sanchez (2007) highlights the fact that employee surveys are mainly designed to enhance organisational communication and measure employee views on a wide range of work-related topics.

The value of using employee satisfaction data to analyse the different generations assists in overcoming stereotyping by providing empirical evidence. Furthermore, organisations can attract, retain and motivate their human resources when they conduct satisfaction surveys and implement interventions that address the satisfaction issues faced by employees (O'Neil, 2005:135). In the next section the research methodology, results and findings are discussed.

\section{Research Methodology}

An employee satisfaction survey was conducted in one of South Africa's largest metropolitans' municipalities (27 611 employees) to determine employees' satisfaction with organisational practices (Martins \& Martins, 2012). One of the specific objectives of the survey was to determine the perceptions of the various biographical groups which include age groups.

\subsection{Data collection approach}

Both electronic and paper collection methods were used to obtain minimum sample levels for all the different departments and business units and across all biographical groups. The electronic medium used was the intranet, which makes it possible for surveys to be conducted effectively and efficiently. The primary reason for utilising this approach was time and cost savings as well as the geographical location of employees. However, due to the diversity in educational levels, workshops were arranged and trained facilitators assisted employees to complete paper questionnaires. To maintain confidentiality, facilitators collected completed questionnaires and forwarded them to the data capturers. In total a $22.93 \%$ response rate was obtained; 6329 employees participated in the survey. The sample consisted of $30.8 \%$ Millennials (1 946 respondents), 28.8\% Generation Xers (1 821 respondents), 40.3\% Baby-Boomers (2 554 respondents) and 8.7\% who did not indicate their age distribution. This is a typical indication of the age profile of the organisation.

\subsection{Measuring instrument}

The measuring instrument that was used was based on the questionnaire of Martins and Von der Ohe (2006), but the terminology was adapted to fit in with the culture of the organisation. The questionnaire measures overall employee satisfaction and was refined by means of focus groups and expert input by human resources practitioners from the different business units. The questionnaire consisted of 13 dimensions with an overall Cronbach alpha reliability of 0.978 . All the items in the questionnaire required the respondent to respond to a five-point Likert scale, where a low rating (1) indicated that the respondents strongly disagreed, and a high rating (5) indicated that they strongly agreed. The questionnaire was then scored for each of the various dimensions.

Structural equation modelling was used to confirm the reliability and validity of the questionnaire. The input type was the covariance matrix. The robust maximum likelihood estimator was used to account for multivariate normality issues (Muthén \& Muthén, 2007). The three generation categories were analysed as continuous variables. Individual items were used as indicator variables. Goodness-of-fit was evaluated using the traditional statistic, Comparative fit index (CFI) .937, Tucker-Lewis index (TLI) .910, Normed fit index (NFI) .936, Relative fit index (RFI) .908, and Incremental fit index (IFI) .937. Although there is little consensus on cut-off values for adequate fit, conventional guidelines were followed whereby fit is considered adequate if CFI, TLI, NFI, RFI and IFI values are $>0.90$ (Hair et al 1995; Schumaker \& Lomax 1996). The reliability of the 13 dimensions was evaluated with Cronbach alpha coefficients. The reliabilities are between .798 and .916 (see table 1).

\subsection{Results of the research}

Non-parametric tests were used for the data analysis because the study involved the use of continuous data. It is usually a plausible alternative to the more stringent parametric tests (Pett, 1997).

For this research the Kruskal-Wallis one-way analysis of variance by ranks, a non-parametric method for testing whether samples originate from the same distribution, was used. It is used for comparing more than two samples that are 
independent, or not related. When the Kruskal-Wallis test leads to significant results, then at least one of the samples is different from the other samples. Since it is a non-parametric method, the Kruskal-Wallis test does not assume a normal distribution, unlike the analogous one-way analysis of variance. However, the test does assume an identically shaped and scaled distribution for each group, except for any difference in medians. Kruskal-Wallis is also used when the examined groups are of unequal size (different number of participants as is the case in this research). The Mann Whitney $\mathrm{U}$ test is used to determine whether two independent samples have the same median and the Kruskal-Wallis test is an omnibus test equivalent to ANOVA for the equality of independent population medians (Tredoux \& Durrheim, 2002).

Differences were tested at the customary Alpha $\leq .05$. The results of table 1 indicate significant differences between the three generation groups for six of the dimensions. It is important to note that Millennials appear to be the most positive group for three of the six dimensions (table 1):

- change management

- employee relations

- vision and mission

The Generation X respondents are significantly more positive about training and development while Baby-Boomers are significantly more positive about communication and teamwork.

Table 1: Kruskal-Wallis Test

\begin{tabular}{|c|c|c|c|c|c|c|c|}
\hline \multirow{2}{*}{\multicolumn{2}{|c|}{ Dimension and reliability }} & \multicolumn{3}{|c|}{ Means } & \multirow[t]{2}{*}{ Chi-Square } & \multirow[t]{2}{*}{ Df } & \multirow[t]{2}{*}{ Asymp. Sig. } \\
\hline & & Millennials & Gen X & Baby-Boomers & & & \\
\hline Vision and mission & .843 & 3.83 & 3.79 & 3.45 & 101.132 & 2 & .000 \\
\hline Values & .822 & 3.96 & 3.93 & 3.94 & .360 & 2 & .835 \\
\hline Diversity & .831 & 3.21 & 3.21 & 3.13 & 3.968 & 2 & .138 \\
\hline Employee relations & .904 & 2.91 & 2.88 & 2.78 & 13.767 & 2 & .001 \\
\hline Teamwork & .831 & 3.40 & 3.40 & 3.49 & 7.768 & 2 & .021 \\
\hline Management & .944 & 3.19 & 3.19 & 3.19 & .103 & 2 & .950 \\
\hline Trust & .819 & 3.25 & 3.28 & 3.24 & .976 & 2 & .614 \\
\hline Communication & .798 & 3.01 & 3.05 & 3.10 & 7.207 & 2 & .027 \\
\hline Training and development & .865 & 3.05 & 3.11 & 3.00 & 7.332 & 2 & .026 \\
\hline Work environment & .783 & 3.23 & 3.29 & 3.23 & 4.600 & 2 & .100 \\
\hline Rewards and recognition & .798 & 2.54 & 2.52 & 2.52 & 1.793 & 2 & .408 \\
\hline Change management & .916 & 2.92 & 2.90 & 2.80 & 15.700 & 2 & .000 \\
\hline Employee engagement & .876 & 3.34 & 3.35 & 3.31 & 2.577 & 2 & .276 \\
\hline
\end{tabular}

Research by the HSRC (Odendaal, 1997) indicates that an average of 3.20 is a good guideline to differentiate between positive and developmental perceptions on a five-point Likert scale. If the recommended 3.20 cut-off point is used to further interpret the results (Castro \& Martins, 2010; Odendaal, 1997) a number of interesting tendencies are noted. Overall all the generation groups experience the following dimensions positively (above 3.20 cut-off):

- vision and mission

- values

- teamwork

- trust

- work environment

- employee engagement

All the generation groups experience the following dimensions as problematic (below 3.20 cut-off point):

- employee relations

- management

- communication

- training and development

- rewards and recognition

- change management

The only dimension which does not fit into any of the above discussed results is diversity, which is experienced more negatively by the Baby-Boomers; however, not significantly lower than the other two generations. For six of the 13 dimensions significant differences were experienced, as mentioned. However, for seven dimensions no significant 
differences were noted. The overall results of the three age groups indicate that the Baby-Boomers experience only two dimensions (teamwork and communication) more positively and three of the statements (see table 2) more positively than the other two generations. It thus appears as if the Baby-Boomers are more negative regarding their levels of employee satisfaction.

A more detailed analysis of the dimensions by statement is portrayed in table 2 . Only the results of the statements with significant differences are displayed and only the results of the dimensions and statements with significant differences are further discussed.

For the dimension of vision and mission the Millennials and Generation X respondents are significantly more aware of the organisation's vision and mission and are excited by it. This supports the findings of the PWC research in South Africa, which indicates that articulating the employer brand and clearly stating corporate responsibility will be critical for Millennials (www.pwc.com/za/en/pres-room/managing-tomorrows-people.jhtml). It is interesting to note that Millennials and the Generation $X$ respondents perceive that their organisation to a greater degree treats them with respect and dignity, and encourages them to participate in decision-making; and they experience that terms and conditions of service are applied fairly. However, the results of all three statements are below the 3.20 cut-off point (employee relations). With regard to change management, there are very similar results for the Millennials and Generation $\mathrm{X}$ respondents, but significantly different expectations from the Baby-Boomers. The change management aspect which appears to be the most important to all three generations is that employees need to understand the need for change, It is, however, of concern that all statements relating to change are perceived as problematic (below 3.20) except understanding the need for change.

Table 2: Results of the Kruskal-Wallis Test

\begin{tabular}{|c|c|c|c|c|c|c|c|}
\hline \multirow{2}{*}{ Dimension } & \multirow{2}{*}{ Abbreviated Statements } & \multicolumn{3}{|c|}{ Means } & \multirow{2}{*}{$\begin{array}{l}\text { Chi- } \\
\text { Square }\end{array}$} & \multirow{2}{*}{ Df } & \multirow{2}{*}{$\begin{array}{l}\text { Asymp. } \\
\text { Sig. }\end{array}$} \\
\hline & & Millennials & Gen X & Baby-Boomers & & & \\
\hline \multirow{2}{*}{$\begin{array}{l}\text { Vision and } \\
\text { mission }\end{array}$} & Aware of vision and mission. & 3.95 & 3.90 & 3.40 & 151.438 & 2 & .000 \\
\hline & Excited by vision and mission. & 3.68 & 3.61 & 3.20 & 111.112 & 2 & .000 \\
\hline \multirow{3}{*}{$\begin{array}{l}\text { Employee } \\
\text { relations }\end{array}$} & Treat employees with respect. & 2.96 & 2.91 & 2.78 & 19.563 & 2 & .000 \\
\hline & Encourages employees to be involved in decision-making & 2.66 & 2.65 & 2.52 & 16.850 & 2 & .000 \\
\hline & Terms and conditions of service are applied fairly. & 2.95 & 2.91 & 2.80 & 12.169 & 2 & .002 \\
\hline \multirow{6}{*}{$\begin{array}{l}\text { Change } \\
\text { manage- } \\
\text { ment } \\
\end{array}$} & $\begin{array}{l}\text { Changes made have had a positive impact on service } \\
\text { delivery }\end{array}$ & 2.93 & 2.86 & 2.78 & 11.272 & 2 & .004 \\
\hline & Understand the need for change. & 3.66 & 3.62 & 3.45 & 20.554 & 2 & .000 \\
\hline & Timeously consulted workplace changes. & 2.72 & 2.69 & 2.62 & 8.987 & 2 & .011 \\
\hline & Encouraged to participate in change. & 2.89 & 2.83 & 2.71 & 18.937 & 2 & .000 \\
\hline & Prepared for new changes & 2.82 & 2.84 & 2.70 & 14.220 & 2 & .001 \\
\hline & Helps to adapt to new job roles and responsibilities. & 2.88 & 2.86 & 2.74 & 13.648 & 2 & .001 \\
\hline \multirow{3}{*}{$\begin{array}{l}\text { Training } \\
\text { and } \\
\text { develop- } \\
\text { ment }\end{array}$} & $\begin{array}{l}\text { Provides training programmes and assistance that meet } \\
\text { job-related needs }\end{array}$ & 2.98 & 3.10 & 2.97 & 9.375 & 2 & .009 \\
\hline & $\begin{array}{l}\text { An individual learning plan which was agreed to with } \\
\text { Manager exists. }\end{array}$ & 3.00 & 3.10 & 2.93 & 14.963 & 2 & .001 \\
\hline & Have received training in terms of individual learning plan & 2.58 & 2.69 & 2.66 & 5.925 & 2 & .052 \\
\hline \multirow[t]{2}{*}{ Teamwork } & Motivate and support each other. & 3.42 & 3.43 & 3.60 & 25.928 & 2 & .000 \\
\hline & Work together as a team. & 3.54 & 3.51 & 3.65 & 15.006 & 2 & .001 \\
\hline $\begin{array}{l}\text { Communi- } \\
\text { cation }\end{array}$ & Regular staff meetings. & 3.17 & 3.24 & 3.45 & 48.188 & 2 & .000 \\
\hline
\end{tabular}

It is important to note that the Millennials and Baby-Boomers experience the questions relating to training and development less positively than do Generation X respondents. In a qualitative study by Masibigiri and Nienaber (2011), in a South African public service organisation focusing on Generation Xers, career growth and development emerged as prominent retention factors for Generation Xers. In the PWC research it appears as if training is also the most highly valued benefit for Millennials (http://www.pwc.com/za/en/press-room/managing-tomorrows-people.jhtml).

Both the dimensions of teamwork and communication as well as the statements indicate significant differences between the generation groups. It appears as if the Baby-Boomers are more comfortable with working as a team or 
participating in meetings than are the other two groups. This might support the PWC research in which it was confirmed that especially Millennials view technology as key to socialising and networking (http://www.pwc.com/za/en/pressroom/managing-tomorrows-people.jhtml).

It is interesting that no significant differences were noted for the dimensions of values, diversity, management, trust, work environment, rewards and recognition, and employee engagement. This again confirms the findings of the PWC research, namely that Millennials want many of the same things from work as the generations before them (www.pwc.com/za/en/pres-room/managing-tomorrows-people.jhtml).

\section{Discussion}

The results of the study highlighted some similar but also interesting new trends regarding the management of the generation groups in a diverse country such as South Africa. The study revealed an intense focus by Millennials on their own training and development. It appears as if Millennials are not satisfied to keep on doing their job without further development and that an individual training plan is an important tool to them for further development. This is supported by the PWC research in South Africa, which found that training and development is the most highly valued benefit for Millennials in the first few years of their career (http://www.pwc.com/za/en/press-room/managing-tomorrowspeople.jhtml). Research by Hite and McDonald (2012) [p 217] indicates that Millennials are "hungry for leadership counsellors - willing to open fresh avenues to their development, affirmation and establishment of their potential..." . It appears from the survey results as if the Generation Xers are the most satisfied group regarding training and development.

Another important finding is the lesser participation in teamwork by Millennials and Generation Xers than BabyBoomers. The study shows a more positive perception by Millennials and Generation Xers toward the organisation's vision and mission, but on the other hand, not a feeling of being treated with dignity and respect (employee relations) by all three generations.

The results of the employee satisfaction study revealed a more positive perception by both Millennials and Generation Xers of change. This is understandable considering these generations are seen as highly educated, opinionated, sophisticated and technologically savvy - all characteristics that can be associated with flexibility and change. However, all three generations experience the dimension overall as problematic.

An area which seems to be more problematic for Millennials is regular staff meetings. Being a more technologyoriented generation and less relationship-building oriented (Chang, 2011), this is understandable. However, this creates a challenge for managers as to how to develop the younger generation's relationship-building skills.

The survey results also show that the generation group with the most knowledge and skills, namely the BabyBoomers, is also the most negative group. Many organisations utilise the skills and knowledge of the Baby-Boomers in coaching and mentoring. It is thus important to increase their satisfaction levels to improve the quality of their inputs. According to Masibigiri and Nienaber (2011:1), retaining the right talent in South African organisations, as is the case internationally, is challenging because of recent problems such as the struggle for talent, skills shortages, employee mobility and the imminent retirement of Baby-Boomers. In summary, the results of the study reveal closer satisfaction levels between Millennials and Generation Xers than with Baby-Boomers.

\section{Conclusion}

In conclusion it appears as if, on the one hand, organisations will need to focus on the things Millennials really need, such as training and development, and developing interpersonal relationship skills. This can improve their relationship motivation and aspects such as social relationships, friendships, affiliation and group work and eventually their employee satisfaction. On the other hand organisations need to focus on the satisfaction levels of the Baby-Boomers and Generation Xers to ensure they put strategies in place to enhance their employee satisfaction. It is especially important to improve the satisfaction levels of the Baby-Boomers as the most negative generation group, as they are the group with the most knowledge and skills and are utilised as mentors and coaches.

Seeyers (PWC research http://www.pwc.com/za/en/press-room/managing-tomorrows-people.jhtml) concluded that Millennials want many of the same things from work as the generations before them, so companies do not need to tear up their people strategies to manage the new generation of workers. What is new is younger people's ability to mobilise into another job if their expectations and ideals are not met.

The results also show that Millennials expect many of the same things from their organisations as the generation before them. Seven of the dimensions show no significant differences between the three generations. The results of this 
research furthermore indicate that organisations need to focus more on change management and especially on aspects such as consulting with employees regarding change, participation in change and preparing employees of all generations for change.

In summary it appears as if organisations need to take note of the similarities between the generations and maintain the strategies for focusing on these. However, also note the different expectations and needs of the various generations and especially the two younger generations. They are the people who will need to step into the jobs of the Baby-Boomers. It thus makes good sense to focus on what needs to be done to improve their employee satisfaction and to retain valuable knowledge for future organisations.

A limitation of this study of generations is that the needs and expectations of the other biographical groups (ie race, gender, age, years of service) related to employee satisfaction are not taken into consideration. One could expect to see differences in their responses in this regard too. Future studies should investigate the mediating or moderating effects in this regard.

\section{References}

Aamodt, M.G. (2007). Industrial/organisational psychology: An applied approach. Belmont, CA: Thomson Higher Education.

Abott, J. (2003). Does employee satisfaction matter? A study to determine whether low employee morale affects customer satisfaction and profits in the business-to-business sector. Journal of Communication Management 7(4):333-339.

Alexander, K. (2011). Mining millennials. Available at http//www.systemiclogic.com/za/?p=898 (accessed 5 September 2011).

Arvey, R.D, Carter, G.V. \& Buerkley, D.K. (1991). Job satisfaction: Dispositional and situational influences. In C.L. Cooper and I.T. Robertson (eds). International Review of Industrial and Organizational Psychology (pp. 6, 359-383). Chichester:Wiley.

Borg, I. \& Mastrangelo, P.M. (2008). Employee surveys in management: Theories, tools and practical applications. Cambridge: Hogrefe $\&$ Huber Publishers.

Bjornebekk, G. (2008). Positive affect and negative affect as modulators of cognition and motivation: The rediscovery of affect in achieving goal theory. Scandinavian Journal of Educational Research 52:153-170.

Burke, R.J. Graham, J. \& Smith, F. (2005). Effects of reengineering on employee satisfaction-customer satisfaction relationship. The TQM Magazine 17(4):358-363.

Castro, M, \& Martins, N. (2010). The relationship between organisational climate and employee satisfaction in a South African Information and Technology Organisation. SA Journal of Industrial Psychology/ SA Tydskrif vir Bedryfsielkunde, Vol 36 (1), 1-9.

Chang, D. (2011). Baby-boomers vs the millennials. Retrieved September 5, 2011 from http://www.citypress.co.za/Columnists/BabyBoomers-vs-the-Millennials-20110702

Clark, A. Oswald, A. \& Warr, P. (1996). Is job satisfaction U-shaped in age? Journal of Occupational and Organisational Psychology 69:57-81.

Codrington, G. \& Grant-Marshall, S. (2006). Mind the gap. Cape Town: Penguin Books.

Comm, C.L. \& Mathaisel, D.F.X. (2000), Spring. Assessing employee satisfaction in service firms: An example in high education. The Journal of Business and Economic Studies, Fairfield, 43-53.

Cordeniz, J.A. (2002). Recruitment, retention and management of Generation X: A focus on nursing professionals. Journal of Healthcare Management, 47(4), 237-244.

Crites, J.O. (1969).Vocational psychology. New York: McGraw-Hill.

DeLong, D.W. (2004). Lost knowledge: Confronting the threat of an aging workforce. Oxford: Oxford University Press.

Döckel, A., Basson, J.S. \& Coetzee, M. (2006). The effect of retention factors on organisational commitment: An investigation of high technology employees. SA Journal of Human Resource Management 4(2):20-28.

Dressler, G. (2009). Fundamentals of human resource management. London: Pearson Education.

Duhon, B. (1998). It's all in our heads. Inform 12(8), 8-14. Available at http://www.0-roquest.umi.com.oasis.unisa.ac.za:80/pqdweb?did= 10485176\&sid=4\&Fmt=3\&clientld=27625\&RQT=309\&VName=PQD_(retrieved March 14, 2006).

Espinoza, C., Ukleja, J. and Rusch, C. (2010). Managing the Millennials: Discover the core competencies for managing today's workforce. John Wiley, Hoboken, NJ.

Finkelstein, L.M. (2012). SIOP'S Impact Hits San Diego. Tip. The Industrial-Organizational Psychologist 50(1), July:138-143.

French, L.W. \& Bell, C.H. (1999). Organisational development: Behavioural sciences interventions for organisation improvement. $6^{\text {th }}$ edition. Upper Saddle River, NJ: Prentice-Hall.

Garlick, R. \& Langley, K. (2007). Reaching Gen Y on both sides of the cash register: As customers and retail employees. Insight Newsletter 10:1-9.

Hair, J.F., Anderson, R.E., Tatham, R.L. \& Black, W.C. (1995). Multivariate data analysis. $4^{\text {th }}$ ed. London: Prentice-Hall.

Hamilton, D. (201). Millennials replacing baby-boomer workforce: Meeting their unique needs. Available at http://drdianehamilton. wordpress.com/2011/01/09/millennials- replacing- baby-boomer (accessed 15 October 2011).

Hite, L.M. and McDonald, K.S. (2012), "Career counselling for Millennials: practitioners' perspectives", in Ng, E.S. and Schweitzer, L. (Eds), Managing the new workforce: International perspectives on the Millennial generation, Edward Elgar, Chelthenham, UK, pp. 204-221 Kochanski, J. \& Ledford, G. 2001. How to keep me: Retaining technical professionals.

Kreitner, R. \& Kinicki, A. (2008). Organizational behavior. Chicago: Irwin 
Kulas, J.T., McInnerney, E.J., DeMuth, F.R. \& Jadwinski, V. (2007). Employee satisfaction and theft: Testing climate perceptions as a mediator. The Journal of Psychology 14(4):389-402.

Küskü, F. (2003). Employee satisfaction in higher education: The case of academic and administrative staff in Turkey. Career Development International 8(7):347-356.

Lawler, E.E. \& Finegold, D. (2000). Individualising the organization: Past, present and future. Organisational Dynamics 29(1):1-15.

Lancaster, L.C. and Stillman, D. (2002) When generations collide: who they are. Why they clash. How to solve the generational puzzle at work. HarperCollins e-books.

Ledimo, O.M. (2012). A longitudinal study of changes in employee satisfaction during transformation: Development of an organisational diagnostic model. Unpublished doctoral thesis. University of South Africa. Pretoria.

Locke, E.A. (1976). The nature and causes of job satisfaction. In D.M. Dunnette (ed.). Handbook of industrial and organizational psychology (pp. 297-349). Chicago, IL: Rand McNally.

Macky, K., Gardner, D., \& Forsyth, S. (2008). Generational differences at work: Introduction and overview. Journal of Managerial Psychology, 23(8), 857-861.

Martins, N. \& Coetzee, M. (2007). Organisational culture, employee satisfaction, perceived leader emotional competency and personality type: An exploratory study in a South African engineering company. SA Journal of Human Resource Management 5(2):20-32.

Martins, N. \& Martins E.C. (2012). in Ng, E.S. and Schweitzer, L. (Eds), Managing the new workforce: International perspectives on the Millennial generation, Edward Elgar, Chelthenham, UK, pp. 152-180, Assessing millennials in the South African context.

Martins, N. \& Von der Ohe, H. (2006). Detecting sub-cultures in an organisation. South African Business Review 10(2):130-49.

Masibigiri, V. \& Nienaber, H. (2011).Factors affecting the retention of Generation X public servants: An exploratory study. SA Journal of Human Resource Management/SA Tydskrif vir Menslikehulpbronbestuur 9(1).

McElroy, J.C. (2001). Managing workplace commitment by putting people first. Human Resources Management Review 11:327-35.

Mclnerney, C. (2002). Knowledge management and the dynamic nature of knowledge. JASIST 53(2).

Michaels, E., Hardfield-Jones, H. \& Axelrod, B. (2001). The war for talent. Cambridge, MA: Harvard Business School Press.

Moore, A. \& Bussin, M. (2012). Reward preferences for generations in selected Information and Communication Technology companies. SA Journal of Human Resource Management/SA Tydskrif vir Menslikehulpbronbestuur 10(1) http://dx.doi.org/10.4102 Isajhrm.v10i1.325.

Muthén, L.K. \& Muthén, B.O. (2007). Mplus Statistical Analysis with Latent Variables: User's Guide. 5th edition. Los Angeles, CA: Muthén \& Muthén.

Nadler, D.A. \& Tushman, M.L. (1980). A model for diagnosing organizational behavior. Organizational Dynamics, 9:35-51

Ndlangamandla, N. (2011). The perceived impact of quality of supervision on employee's job satisfaction. In J.H. Westover (ed.) Examining job satisfaction: Causes, outcomes, and comparative differences. Champaigne, IL: Common Ground Publishing, pp. 31-48.

Odendaal, A. (1997). Deelnemende bestuur en korporatiewe kultuur: Onafhanklike konstrukte? (Participative management and corporate culture: Independent constructs?). Unpublished Master's dissertation, Rand Afrikaans University, Johannesburg.

O'Neil, M. (2005). Employee care, a vital antecedent to customer care in the health care industry: An exploratory investigation of the employee satisfaction construct at North East Alabama Regional Medical Center. International Journal of Health Care Quality Assurance 18(2):131-151.

Oxygenz Report, (2010), Global Work Place Innovation: Oxygenz Country Report: South Africa. University of Pretoria (Retrieved from the Internet 7 January 2014 from http://www.johnsoncontrols.com/content/dam/WWW/jci/be/global_workplace_ innovation/ oxygenz/South Africa Oxygenz report low res.pdf

Pett, M.A. (1997). Non-parametric statistics for health care research: Statistics for small samples and unusual distributions. London: Sage.

Pollitt, D. (2005). Diversity is about more than observing the letter of the law. Human Resource Management International Digest 13(4):7-40.

Rich, P. (2012). Engaging the multi-generational workforce. (Retrieved 1 October 2012 from http://www.hrmreport.com/article/Engagingthe Multi-generational-Workforce/).

Robinson, I. (2006). Human resource management in organisations. London: Chartered Institute of Personnel and Development.

Ryder, N. (1965). The cohort as a concept in the study of social change. American Sociological Review 30:843-61.

Robbins, S.P. \& Judge, T.A. (2010). Essentials of organizational behaviour. Boston: Pearson.

Rollinson, D. (2005). Organisational behaviour and analysis: an integrated approach. London: Prentice-Hall.

Salkowitz, R. (2008). Generation blend: Managing across the technology age gap. John Wiley \& Sons, Inc. New Jersey.

Sanchez, P.M. (2007). The employee survey: More than asking questions. Journal of Business Strategy 28(2):48-56.

Schumacker, R.E. \& Lomax, R.G. (1996). A beginner's guide to structural equation modelling. Mahwah, NJ: Lawrence Erlbaum

Smith, C. (2011). Black to the future - South Africa's Gen-Y. Available at http://www.tomorrowtoday.co.za/2010/03/02/\%E2\%90\%9 Cblack- to- the future\%E2\%80 (accessed 5 September 2011).

Schneider, B. \& Snyder, R.A. (1975). Some relationships between job satisfaction and organizational climate. Journal of Applied Psychology, 60(3), 318-328.

Tredoux, C. \& Durrheim, K. (2002). Numbers, hypotheses \& conclusions: A course in statistics for the social sciences. Cape Town. UCT Press.

Van Aardt, I. (2012). A review of youth unemployment in South Africa, 2004 to 2011. South African Journal of Labour Relations 
36(1):54-68.

Weiss, H.M. (2002). Deconstructing job satisfaction: separating evaluations, beliefs and affective experiences. Human Resource Management Review, 12(2), 173-194.

Westover, J.H. (2011). The relationship between job satisfaction and other important individual, organizational and social outcomes. In J.H. Westover (ed.), Examining job satisfaction: Causes, outcomes, and comparative differences. Champaigne, IL: Common Ground Publishing, pp. 113-30. 